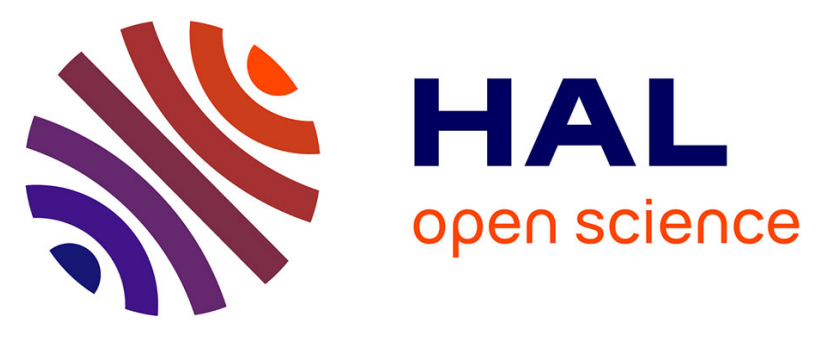

\title{
Monitoring plasma voriconazole levels following intravenous administration in critically ill patients: an observational study
}

Pavlos Myrianthefs, Sophia L. Markantonis, Penelope Evaggelopoulou, Stratos Despotelis, Effimia Evodia, Dimitris Panidis, George Baltopoulos

\section{To cite this version:}

Pavlos Myrianthefs, Sophia L. Markantonis, Penelope Evaggelopoulou, Stratos Despotelis, Effimia Evodia, et al.. Monitoring plasma voriconazole levels following intravenous administration in critically ill patients: an observational study. International Journal of Antimicrobial Agents, 2010, 35 (5), pp.468. 10.1016/j.ijantimicag.2009.12.021 . hal-00578291

\section{HAL Id: hal-00578291 https://hal.science/hal-00578291}

Submitted on 19 Mar 2011

HAL is a multi-disciplinary open access archive for the deposit and dissemination of scientific research documents, whether they are published or not. The documents may come from teaching and research institutions in France or abroad, or from public or private research centers.
L'archive ouverte pluridisciplinaire HAL, est destinée au dépôt et à la diffusion de documents scientifiques de niveau recherche, publiés ou non, émanant des établissements d'enseignement et de recherche français ou étrangers, des laboratoires publics ou privés. 


\section{Accepted Manuscript}

Title: Monitoring plasma voriconazole levels following intravenous administration in critically ill patients: an observational study

Authors: Pavlos Myrianthefs, Sophia L. Markantonis, Penelope Evaggelopoulou, Stratos Despotelis, Effimia Evodia,

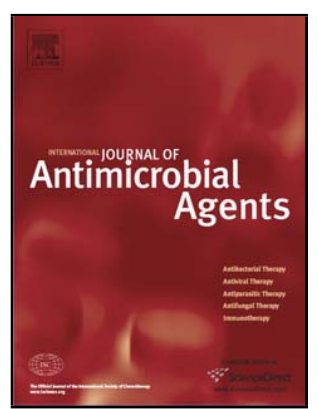
Dimitris Panidis, George Baltopoulos

PII:

DOI:

Reference: $\quad$ ANTAGE 3227

S0924-8579(10)00024-5

To appear in: International Journal of Antimicrobial Agents

Received date: $\quad 25-11-2009$

Revised date: $\quad 20-12-2009$

Accepted date: $\quad$ 23-12-2009

Please cite this article as: Myrianthefs P, Markantonis SL, Evaggelopoulou P, Despotelis S, Evodia E, Panidis D, Baltopoulos G, Monitoring plasma voriconazole levels following intravenous administration in critically ill patients: an observational study, International Journal of Antimicrobial Agents (2008), doi:10.1016/j.ijantimicag.2009.12.021

This is a PDF file of an unedited manuscript that has been accepted for publication. As a service to our customers we are providing this early version of the manuscript. The manuscript will undergo copyediting, typesetting, and review of the resulting proof before it is published in its final form. Please note that during the production process errors may be discovered which could affect the content, and all legal disclaimers that apply to the journal pertain. 


\section{Monitoring plasma voriconazole levels following intravenous administration in critically ill patients: an observational study}

Pavlos Myrianthefs ${ }^{a}$, Sophia L. Markantonis ${ }^{\mathrm{b}, \star}$, Penelope Evaggelopoulou ${ }^{a}$, Stratos Despotelis ${ }^{b}$, Effimia Evodia ${ }^{a}$, Dimitris Panidis ${ }^{b}$, George Baltopoulos ${ }^{a}$

a Intensive Care Unit, 'KAT' Hospital, School of Nursing, Athens University, Athens, Greece

${ }^{\mathrm{b}}$ Athens University, Faculty of Pharmacy, Laboratory of Biopharmaceutics and Pharmacokinetics, Athens 157.71, Greece

ARTICLE INFO

Article history:

Received 25 November 2009

Accepted 23 December 2009

Keywords:

Voriconazole

Critically ill patients

Normal to moderate renal impairment

Plasma concentration monitoring

Pharmacokinetics

* Corresponding author. Present address: Faculty of Pharmacy, Department of Pharmaceutical Technology, Laboratory of Biopharmaceutics and Pharmacokinetics, 
University of Athens, Panepistimiopolis, Athens 157.71, Greece. Tel.: +30 210727 4676; fax: +30 2107274027 .

E-mail address: kyroudi@pharm.uoa.gr (S.L. Markantonis). 


\section{ABSTRACT}

Data relating to the pharmacokinetics of voriconazole in critically ill patients are lacking. A prospective observational study was conducted on 18 non-consecutive critically ill patients aged 24-97 years, comprising 12 patients with normal renal function (NRF) [creatinine clearance $\left(\mathrm{CL}_{\mathrm{Cr}}\right) \geq 60 \mathrm{~mL} / \mathrm{min}$ ] and 6 patients with moderate renal impairment (MRI) $\left(\mathrm{CL}_{\mathrm{Cr}} 40-55 \mathrm{~mL} / \mathrm{min}\right)$, administered voriconazole intravenously (6 mg/kg loading dose and 3-4 mg/kg twice daily thereafter) in order to determine the suitability of these doses in this patient population. Steady-state blood levels were monitored and liver and renal function were recorded throughout treatment. Large variability in patient plasma levels was observed, ranging from $37 \%$ at $\leq 1 \mathrm{mg} / \mathrm{L}$ (minimum inhibitory concentration at which, for most fungal pathogens, $90 \%$ of isolates are susceptible) to $19 \%$ at $>5.5 \mathrm{mg} / \mathrm{L}$. Moreover, maintaining trough concentrations above clinical breakpoints was not consistently achieved because 16/30 (53\%) were $\leq 1 \mathrm{mg} / \mathrm{L}$. In a few MRI patients, average concentrations were found to be significantly different compared with those of NRF patients administered the same dose, however this difference was not noted in pharmacokinetic parameters following dose normalisation. None of the patients experienced deterioration in renal or liver function. Recommended voriconazole doses are inadequate to achieve drug concentrations $>1 \mu \mathrm{g} / \mathrm{mL}$ over the entire dosing interval in some critically ill patients. 


\section{Introduction}

Fungal infections remain an important and serious infectious complication for critically ill Intensive Care Unit (ICU) patients. These patients are particularly susceptible to fungal infections because of physical barrier disruption, immune system depression, excessive antibiotic use, poor gut motility and the application of a plethora of medical and surgical interventions including central venous catheter placement and other intravascular devices as well as abdominal surgery. Several antifungal treatment strategies are applied in ICU patients (prophylactic, empirical, pre-emptive and definite treatment), but in the clinical setting the optimal timing, dosage, duration and choice of antifungal agents largely remain a matter of controversy $[1,2]$.

Voriconazole, a widely used broad-spectrum triazole antifungal agent, is frequently used in ICU patients with severe fungal infections. It is extensively metabolised hepatically by the cytochrome P450 (CYP) system and $<2 \%$ of an orally or intravenously administered dose is excreted unchanged in the urine [3]. To date, clinical studies have indicated that clearance of voriconazole is not influenced by renal function [3]. However, accumulation of the potentially nephrotoxic solubilising excipient sulfobutyl ether- $\beta$-cyclodextrin (SBECD) contained in its intravenous (i.v.) formulation has been described in patients with moderate to severe renal impairment [serum creatinine $\left(\mathrm{Sr}_{\mathrm{Cr}}\right)$ levels $>2.5 \mathrm{mg} / \mathrm{dL}$ ] due to a linear relationship between clearance of the excipient and creatinine clearance $\left(\mathrm{CL}_{\mathrm{Cr}}\right)[4,5]$. Furthermore, whilst receiving i.v. voriconazole, reversible elevations in $\mathrm{Sr}_{\mathrm{Cr}}$ from baseline were documented in clinical trials on patients with impaired renal function [6,7]. Therefore, in patients with reduced renal function $\left(\mathrm{Sr}_{\mathrm{Cr}}\right.$ levels $\left.>2.5 \mathrm{mg} / \mathrm{dL}\right)$, oral voriconazole is 
recommended unless assessment of the risk-benefit ratio justifies the use of i.v. voriconazole [3].

Voriconazole exhibits ca. 100-fold variability in drug levels in individuals receiving the same dosage [8]. Random concentrations $<2.05 \mathrm{mg} / \mathrm{L}$ have been associated with suboptimal therapeutic outcome, and high concentrations with elevated liver function test values [9] as well as central nervous system [10], ocular and other potential dose-related toxicities [11]. High voriconazole levels have been noted in patients with critical illness [8]. Therefore, there is a need to establish what steady-state levels are achieved in the critically ill following i.v. infusion of voriconazole and to interpret their effect on outcome [8], liver function [9], renal function due to SBECD accumulation [4-6] and other potential concentration-related toxicities [11] in order to provide appropriate information to facilitate dose selection and dosage adjustment requirements in these patients. Accordingly, the aim of this study was to measure voriconazole plasma levels following i.v. administration to critically ill patients with or without renal dysfunction and to investigate its safety profile in terms of adverse effects on renal function.

\section{Patients and methods}

\subsection{Study design}

This was a prospective, open-label, uncontrolled observational study. The study protocol submitted for review stated that only patients receiving voriconazole as medically indicated according to the attending physician would be eligible for participation and that eight blood samples would be collected from each patient to 
monitor steady-state drug levels and to determine voriconazole pharmacokinetic parameters. The Scientific and Ethics Committees of the 'KAT' Hospital (Athens, Greece) and the Athens University School of Nursing deliberated over the requirements of the protocol in light of the frequent blood sampling for routine laboratory tests and cultures typically needed for optimal patient care in ICUs and the intended naturalistic nature of the study and decided to approve the study protocol waiving informed consent from each patient.

\subsection{Study population}

Patients were included in the study if they had an indication to receive voriconazole as prophylactic, empirical, pre-emptive or definite treatment.

\subsection{Inclusion criteria}

Inclusion criteria were i.v. administration of voriconazole for $\geq 72 \mathrm{~h}$, age $>18$ years, normal hepatic function, and normal renal function (NRF) $\left(\mathrm{CL}_{\mathrm{Cr}} \geq 60 \mathrm{~mL} / \mathrm{min}\right)$ up to moderate renal impairment (MRI) $\left(\mathrm{CL}_{\mathrm{Cr}} 40-55 \mathrm{~mL} / \mathrm{min}\right)$.

\subsection{Exclusion criteria}

Exclusion criteria were administration of medications known to be inhibitors or inducers of or to in any way interact with voriconazole and/or a history of hypersensitivity to azoles. 


\subsection{Patient data collected and recorded}

For each eligible patient, their age, sex, weight, height, $\mathrm{CL}_{\mathrm{Cr}}$, urea level, hepatic function tests, disease severity at the time of admission to the ICU based on the Acute Physiology and Chronic Health Evaluation (APACHE) II score, Simplified Acute Physiology Score II (SAPS II), Sequential Organ Failure Assessment (SOFA) scores and Glasgow scale, voriconazole dose and concomitant administration of potentially nephrotoxic drugs such as aminoglycosides, colistin, vancomycin and teicoplanin were recorded.

Patients were divided into two subgroups according to their renal function status, i.e. NRF or MRI (see Inclusion criteria, Section 2.3).

Liver and renal function tests were followed up at baseline, Day 5, Day 10 and at the end of therapy to identify possible adverse effects. Liver function tests included serum alanine and aspartate aminotransferases, alkaline phosphatase, $\gamma$-glutamyl transpeptidase, total bilirubin and conjugated bilirubin. To assess the impact of i.v. voriconazole administration on renal and liver function: (i) renal damage due to accumulation of the solvent vehicle SBECD in study patients with MRI was defined as an increase of $\geq 2$ times the initial $\mathrm{Sr}_{\mathrm{Cr}}$ level, or start of an extrarenal depuration procedure during voriconazole therapy; and (ii) liver damage was defined as an increase of $\geq 4$ times the initial serum concentration of liver enzymes, or $\geq 2$ times in patients with previous impaired liver function, as previously characterised by AlvarezLerma et al. [12]. 


\subsection{Drug administration and collection and analysis of plasma samples}

All patients were administered a loading dose of $6 \mathrm{mg} / \mathrm{kg}$ voriconazole as a 30-min i.v. infusion followed by a maintenance dose of $3-4 \mathrm{mg} / \mathrm{kg}$ as a $30-\mathrm{min}$ i.v. infusion every $12 \mathrm{~h}$ for a period of at least $72 \mathrm{~h}$.

Blood samples $(5 \mathrm{~mL})$ were collected from patients through an arterial catheter just before the initiation of infusion, at the end of infusion and at 1.5, 2.5, 4, 6, 9 and $12 \mathrm{~h}$ thereafter. All samples were taken when voriconazole blood levels were considered to be at steady state. All collected samples were centrifuged immediately at 3500 rpm for 5 min at ca. $4{ }^{\circ} \mathrm{C}$ and the acquired plasma was stored at $-70{ }^{\circ} \mathrm{C}$ until analysis.

Voriconazole plasma concentrations were determined using a previously validated high-performance liquid chromatography (HPLC) method [13]. Calibration curves for voriconazole were linear over the range $200-10000 \mathrm{ng} / \mathrm{mL}$. The lower limit of quantification was $50 \mathrm{ng} / \mathrm{mL}$. Coefficients of variation (CVs) for intraday and interday precision were $0.5-0.6 \%$ and $1.2-7.5 \%$, respectively, at drug concentrations of 200 , 600,4000 and $10000 \mathrm{ng} / \mathrm{mL}$.

\subsection{Statistical analysis}

Quantitative variables are expressed as mean \pm standard deviation (S.D.) for normally distributed variables or as median and range when the distribution departed from normality. Study variables (demographic data, APACHE II , SAPS II and SOFA scores, use of potentially nephrotoxic drugs) in patients with NRF and those with MRI were compared using Student's $t$-test or Mann-Whitney U-test for continuous 
variables or using Fisher's exact test for categorical data. All reported $P$-values are two-sided. A $P$-value of $<0.05$ was considered statistically significant. Statistical processing and data analysis were performed with GraphPad Prism 4 software (GraphPad Software Inc., La Jolla, CA).

\subsection{Pharmacokinetic evaluations}

Pharmacokinetic parameters for voriconazole in serum were estimated from the concentration-time data of individual patients by non-compartmental, steady-state analysis using the WinNonlin pharmacokinetic software package (Pharsight Corp., Mountain View, CA).

\section{Results}

In total, 18 ICU patients aged 24-97 years required antifungal therapy and participated in the study between March 2006 and February 2008. Six of these patients were characterised as having MRI and twelve as having NRF at the beginning of voriconazole treatment. The demographic characteristics of the patients are presented in Table 1. All patients required intubation and mechanical ventilation for the reasons listed in Table 1. Laboratory values regarding white blood cell counts and liver and renal function tests during voriconazole administration are shown in Table 2. During the course of treatment with voriconazole, no clinically significant renal or liver function deterioration/damage (as defined in Section 2.5) occurred in any of the patients with or without renal impairment. 
Fourteen patients received empirical antibiotic treatment, two patients received preemptive treatment and two were treated for microbiologically documented candidaemia. Voriconazole was administered on Day $14.8 \pm 3.3$ of ICU hospitalisation for a mean duration of $11.0 \pm 3.6$ days. Mean length of ICU stay was $46.7 \pm 22.5$ days. Other co-administered antimicrobial agents were linezolid (4 patients), meropenem (14 patients), vancomycin (8 patients) and colistin (12 patients). All drugs were administered as clinically indicated by the attending physician.

Blood sampling was performed on Day $3.8 \pm 0.2$. In total, 139 plasma samples were measured (ca. 8 samples from each patient). For two patients (Patients 16 and 17) only $12-\mathrm{h} C_{\min }$ values were available, whilst in another patient (Patient 3) the estimated elimination half-life $\left(t_{1 / 2}\right)$ was $68.4 \mathrm{~h}$ so a comparison could not be made (Table 3)The median (range) minimum plasma concentration $\left(C_{\min }\right)$ was $0.79 \mathrm{mg} / \mathrm{L}$ $(0.08-5.62 \mathrm{mg} / \mathrm{L})$ at time 0 and $0.80 \mathrm{mg} / \mathrm{L}(0.15-5.95 \mathrm{mg} / \mathrm{L})$ at $12 \mathrm{~h}$, indicating that steady state had been achieved in the 13 patients for which both $C_{\min }$ values were determined..

No correlation was found between mean concentrations measured and voriconazole doses administered in the 18 study patients (Table 3). Significant intersubject variation in plasma concentrations was observed at each sampling time for those patients administered $200 \mathrm{mg}(n=4)(\mathrm{CV} 80-120 \%)$ and $240 \mathrm{mg}(n=4)$ (CV 96$145 \%$ ). An increase in dose from $200 \mathrm{mg}$ (4 patients) to $300 \mathrm{mg}$ (2 patients) to 400 mg (2 patients) did not achieve a 2.3-2.5-fold increase in mean steady-state plasma concentration, as previously reported [3], with mean concentrations of $2.8 \pm 2.4 \mathrm{mg} / \mathrm{L}$, 
$2.9 \pm 2.0 \mathrm{mg} / \mathrm{L}$ and $2.7 \pm 2.3 \mathrm{mg} / \mathrm{L}$, respectively. Corresponding mean maximum plasma concentration $\left(C_{\max }\right)$ values of voriconazole were $5.2,6.2$ and $6.9 \mathrm{mg} / \mathrm{L}$, respectively.

In the subgroups of patients with and without renal function impairment, the mean (S.D.) values for $\mathrm{CL}_{\mathrm{Cr}}$ throughout voriconazole administration are shown in Table 2. The number of patients in both groups administered potentially nephrotoxic drugs concomitantly with voriconazole were: colistin (5) or gentamicin (1) or hydrocortisone (1) alone; colistin with vancomycin (3) or hydrocortisone (2) or both (2); vancomycin with hydrocortisone (2); and gentamicin with vancomycin (1). There were no statistically significant differences between patients with normal renal function and renal insufficiency at the start of voriconazole treatment with regard to demographic data, underlying illnesses or concomitant administration of nephrotoxic drugs, with the exception of age $(P=0.0267)$. Average steady-state concentrations in the MRI compared with the NRF patients were significantly different following administration of the $320 \mathrm{mg}$ dose $(P<0.05)$ and $240 \mathrm{mg}$ dose $(P<0.001)$, but were not significant for the $200 \mathrm{mg}$ and $300 \mathrm{mg}$ doses. Steady-state pharmacokinetic parameters for voriconazole, estimated from the concentration-time data for all 18 critically ill patients with or without renal impairment, are presented in Table 3. Following dose normalisation based on the mean administered voriconazole dose of $272 \mathrm{mg}$, median (range) area under the curve (AUC) and apparent volume of distribution and clearance at steady state $\left(\mathrm{Vd}_{\mathrm{app}, \mathrm{ss}}\right.$ and $\mathrm{CL}_{\text {app,ss}}$, respectively) values for NRF patients were $12.9 \mathrm{mg} \mathrm{h} / \mathrm{L}(2.4-100.6 \mathrm{mg} \mathrm{h} / \mathrm{L}), 246.6 \mathrm{~L}$ (36.7-951.9 L) and 20.6 L/h (3.0113.2 L/h) and for MRI patients were $44.4 \mathrm{mg} \mathrm{h} / \mathrm{L}(5.1-93.6 \mathrm{mg} \mathrm{h} / \mathrm{L}), 198.1 \mathrm{~L}(28.8-$ 498.2 L) and 5.7 L/h (4-59.5 L/h), respectively (not statistically significant) (Table 3). 


\section{Discussion}

In the present study, we found that the recommended voriconazole dose of 3-4 $\mathrm{mg} / \mathrm{kg}$ twice daily was inadequate to achieve and maintain drug concentrations $>1$ $\mu \mathrm{g} / \mathrm{mL}$ over the entire dosing interval (trough level) in some of our critically ill patients. Moreover, in accordance with our defined safety criteria, i.v. voriconazole treatment was not associated with either renal or liver damage in NRF and MRI patients.

To our knowledge, this is the first study to describe the pharmacokinetics of voriconazole in critically ill patients with or without renal insufficiency. Voriconazole exhibits non-linear pharmacokinetics due to saturation of its metabolism and as a result small changes in the i.v. dose may result in disproportionate changes in plasma concentrations [14]. In addition, terminal half-life estimations are dependent on the dose and are not indicative of accumulation or elimination of the drug. In the study patients, mean plasma concentrations did not increase with increasing dose of the drug from $200 \mathrm{mg}$ to $400 \mathrm{mg}$. No correlation was found between administered voriconazole dose and achieved plasma concentration. Standard doses of voriconazole produced highly variable drug levels in plasma from $<0.1 \mathrm{mg} / \mathrm{L}$ to 11.4 $\mathrm{mg} / \mathrm{L}$ (Table 3). Multiple factors have been found to be associated with this large variability: non-linear saturable pharmacokinetics; drug-drug interactions; liver disease; patient age (in particular with respect to children); and genetic polymorphism of the cytochrome CYP2C19 [15-18]. Some recent clinical observations have suggested that underdosing and overdosing of voriconazole may influence the efficacy and safety of therapy [11,19-22]. 
A few studies have attempted to evaluate the relationship between voriconazole exposure and treatment efficacy. In vitro pharmacodynamic studies have shown the maximum fungicidal activity of voriconazole is around two to three times the minimum inhibitory concentration (MIC) $[23,24]$. Based on a review of laboratory and clinical data, the Antifungal Susceptibility Subcommittee of the Clinical and Laboratory Standards Institute have proposed interpretive MIC breakpoints for voriconazole and Candida spp. as follows: susceptible $\leq 1 \mathrm{mg} / \mathrm{L}$; susceptible dose-dependent, $2 \mathrm{mg} / \mathrm{L}$; and resistant $\geq 4 \mathrm{mg} / \mathrm{L}$ [25]. These recommendations suggest that voriconazole concentrations should be maintained $>1 \mathrm{mg} / \mathrm{L}$ over the entire dosing interval (trough level). In addition, voriconazole trough blood levels $>5.5 \mathrm{mg} / \mathrm{L}$ have been reported to be possibly associated with toxicity [10]. Large variability in voriconazole levels was observed in our patients, ranging from $37 \%$ at $\leq 1 \mathrm{mg} / \mathrm{L}$ (the MIC at which, for most fungal pathogens, $90 \%$ of isolates are susceptible) to $19 \%$ at $>5.5 \mathrm{mg} / \mathrm{L}$. In fact, in 7 of the 18 study patients $80 \%$ of the voriconazole levels measured were $\leq 1 \mathrm{mg} / \mathrm{L}$. Sixteen (53\%) of the thirty measured trough concentrations were $\leq 1 \mathrm{mg} / \mathrm{L}$ and only $6 \%$ were $>5.5 \mathrm{mg} / \mathrm{L}$.

The very limited literature pertinent to the administration of voriconazole in critically ill patients did not allow direct comparisons to be made between our estimated pharmacokinetic parameters and those of previous studies. In an earlier study in eight critically ill patients administered voriconazole $200 \mathrm{mg}$ or $250 \mathrm{mg}$ twice daily, mean \pm S.D. plasma concentrations of voriconazole for trough and peak were, respectively, $4.6 \pm 2.8 \mathrm{mg} / \mathrm{L}$ and $6.4 \pm 4.3 \mathrm{mg} / \mathrm{L}[26]$ compared with $1.65 \pm 2.02 \mathrm{mg} / \mathrm{L}$ and $5.2 \pm 3.9 \mathrm{mg} / \mathrm{L}$ in our study patients administered $200-250 \mathrm{mg}$ doses. In the present study, the mean estimated $\mathrm{Vd}_{\mathrm{app}, \mathrm{ss}}$ value of $290.9 \mathrm{~L}$ or $4.5 \mathrm{~L} / \mathrm{kg}$ following 
dose normalisation (mean administered dose $272 \mathrm{mg}$ ) was similar to that reported previously, i.e. $2-4.6 \mathrm{~L} / \mathrm{kg}$ [27]. In contrast, our $t_{1 / 2}$ estimations ranged from $5.8 \mathrm{~h}$ to $21.8 \mathrm{~h}$ compared with a reported $t_{1 / 2}$ of ca. $6 \mathrm{~h}$ [27]. However, our estimations were longer than the duration of sampling in three of the NRF patients (see Table 3) and therefore must be regarded as only rough estimations.

The lack of influence of renal function on the pharmacokinetics of voriconazole has been reported $[3,7]$. The mean voriconazole concentrations in our MRI patients compared with NRF patients were found to be significantly different following administration of $320 \mathrm{mg}$ and $240 \mathrm{mg}$ doses, but this finding was based on a very limited number of patients, i.e. two NRF patients versus one MRI patient and three NRF patients versus one MRI patient, respectively, so the results cannot be considered definitive. Furthermore, pharmacokinetic parameters following dose normalisation did not differ significantly between the study patients with and without renal impairment.

\section{Conclusions}

The principal finding of this observational study was that i.v. administration of voriconazole in 18 critically ill patients was associated with a $37 \%$ prevalence of possibly inadequate plasma levels (i.e. $\leq 1 \mathrm{mg} / \mathrm{L}$ ). No clear reason can be offered to explain these low concentrations besides the possibility that certain patients may have been homozygous extensive metabolisers, particularly since our patients were not receiving concomitant medications that might have induced voriconazole metabolism. 
Similar to other voriconazole studies, a wide range of concentrations was observed. A greater than proportional increase in exposure (AUC) was not observed with increasing drug dose. Higher voriconazole plasma concentrations were observed in a few patients with MRI compared with NRF, but despite probable SBECD accumulation, deterioration of renal function was not noted in these patients. Also, none of the patients experienced deterioration in liver function during voriconazole administration.

This study had several limitations. The small sample size, unknown patient genotypes and range of voriconazole doses administered limited the value of the results. However, the findings indicate that administration of voriconazole in critically ill patients needs to be studied further, as additional data are required to facilitate the therapeutic drug monitoring of this antifungal agent in this patient population.

\section{Funding}

This research was funded entirely by the University of Athens.

\section{Competing interests}

None declared.

\section{Ethical approval}

Scientific and Ethics Committees of 'KAT' Hospital and the Athens University School of Nursing (Athens, Greece). 


\section{References}

[1] Blot S, Dimopoulos G, Rello J, Vogelaers D. Is Candida really a threat in the ICU? Curr Opin Crit Care 2008;14:600-4.

[2] Rüping MJ, Vehreschild JJ, Cornely OA. Patients at high risk of invasive fungal infections: when and how to treat. Drugs 2008;68:1941-62.

[3] FDA Antiviral Drugs Advisory Committee. Briefing document for voriconazole (oral and intravenous formulations). FDA Antiviral Drugs Advisory Committee; 2001. http://www.fda.gov/ohrms/dockets/ac/01/briefing/3792b2_01_Pfizer.pdf [accessed 20 January 2010].

[4] Tomaszewski K, Purkins L. The pharmacokinetics and safety of sulphobutylether$\beta$-cyclodextrin (SBECD). In: Program and abstracts of the 41st Interscience Conference on Antimicrobial Agents and Chemotherapy (ICAAC); 16-19 December 2001; Chicago, IL. Washington, DC: ASM Press; 2001. Abstract 23.

[5] Von Mach MA, Burhenne J, Weilemann LS. Accumulation of the solvent vehicle sulphobutylether beta cyclodextrin sodium in critically ill patients treated with intravenous voriconazole under renal replacement therapy. BMC Clin Pharmacol $2006 ; 6: 6$.

[6] US Food and Drug Administration. Background document for the Antiviral Drug Products Advisory Committee meeting. FDA; 2001. http://www.fda.gov/ohrms/dockets/ac/01/briefing/3792b2_02_FDAvoriconazole.htm [accessed 20 January 2010].

[7] Abel S, Allan R, Gandelman K, Tomaszewski K, Webb DJ, Wood ND. Pharmacokinetics, safety and tolerance of voriconazole in renally impaired subjects: two prospective, multicentre, open-label, parallel-group volunteer studies. Clin Drug Invest 2008;28:409-20. 
[8] Hope WW, Billaud EM, Lestner J, Denning DW. Therapeutic drug monitoring for triazoles. Curr Opin Infect Dis 2008;21:580-6.

[9] Tan K, Brayshaw N, Tomaszewski K, Troke P, Wood N. Investigation of the potential relationships between plasma voriconazole concentrations and visual adverse events or liver function test abnormalities. J Clin Pharmacol 2006;46:235-43.

[10] Pascual A, Calandra T, Bolay S, Buclin T, Bille J, Marchetti O. Voriconazole therapeutic drug monitoring in patients with invasive mycoses improves efficacy and safety outcomes. Clin Infect Dis 2008;46:201-11.

[11] Boyd AE, Modi S, Howard SJ, Moore CB, Keevil BG, Denning DW. Adverse reactions to voriconazole. Clin Infect Dis 2004;39:1241-4.

[12] Alvarez-Lerma F, Allepuz-Palau A, Garcia MP, Angeles Leon M, Navarro A, Sanchez-Ruiz H, et al.; Voriconazole Study Group in Critically III Patients. Impact of intravenous administration of voriconazole in critically ill patients with impaired renal function. J Chemother 2008;20:93-100.

[13] Gage R, Stopher DA. A rapid HPLC assay for voriconazole in human plasma. J Pharm Biomed Anal 1998;17:1449-53.

[14] Trifilio S, Pennick G, Pi J, Zook J, Golf M, Kaniecki K, et al. Monitoring plasma voriconazole levels may be necessary to avoid subtherapeutic levels in hematopoietic stem cell transplant recipients. Cancer 2007;109:1532-5.

[15] Johnson LB, Kauffman CA. Voriconazole: a new triazole antifungal agent. Clin Infect Dis 2003;36:630-7.

[16] Dodds Ashley ES, Lewis R, Lewis JS, Martin C, Andes D. Pharmacology of systemic antifungal agents. Clin Infect Dis 2006;43(Suppl 1):S28-39. 
[17] Hyland R, Jones BC, Smith DA. Identification of the cytochrome P450 enzymes involved in the $\mathrm{N}$-oxidation of voriconazole. Drug Metab Dispos 2003;31:540-7.

[18] Walsh TJ, Karlsson MO, Driscoll T, Arguedas AG, Adamson P, Saez-Llorens $X$, et al. Pharmacokinetics and safety of intravenous voriconazole in children after single- or multiple-dose administration. Antimicrob Agents Chemother 2004;48:2166-72.

[19] Smith J, Safdar N, Knasinski V, Simmons W, Bhavnani SM, Ambrose PG, et al. Voriconazole therapeutic drug monitoring. Antimicrob Agents Chemother $2006 ; 50: 1570-2$.

[20] Denning DW, Ribaud P, Milpied N, Caillot D, Herbrecht R, Thiel E, et al. Efficacy and safety of voriconazole in the treatment of acute invasive aspergillosis. Clin Infect Dis 2002;34:563-71.

[21] Imhof A, Schaer DJ, Schanz U, Schwarz U. Neurological adverse events to voriconazole: evidence for therapeutic drug monitoring. Swiss Med Wkly 2006;136:739-42.

[22] Trifilio S, Ortiz R, Pennick G, Verma A, Pi J, Stosor V, et al. Voriconazole therapeutic drug monitoring in allogeneic hematopoietic stem cell transplant recipients. Bone Marrow Transplant 2005;35:509-13.

[23] Purkins L, Wood N, Ghahramani P, Greenhalgh K, Allen MJ, Kleinermans D. Pharmacokinetics and safety of voriconazole following intravenous- to oral-dose escalation regimens. Antimicrob Agents Chemother 2002;46:2546-53.

[24] Andes D, Marchillo K, Stamstad T, Conklin R. In vivo pharmacokinetics and pharmacodynamics of a new triazole, voriconazole, in a murine candidiasis model. Antimicrob Agents Chemother 2003;47:3165-9. 
[25] Pfaller MA, Diekema DJ, Ostrosky-Zeichner L, Rex JH, Alexander BD, Andes D, et al. Correlation of MIC with outcome for Candida species tested against voriconazole: analysis and proposal for interpretive breakpoints. J Clin Microbiol 2006;44:819-26.

[26] Mohammedi I, Piens MA, Padoin C, Robert D. Plasma levels of voriconazole administered via a nasogastric tube to critically ill patients. Eur J Clin Microbiol Infect Dis 2005;24:358-60.

[27] Theuretzbacher U, Ihle F, Derendorf H. Pharmacokinetic/pharmacodynamic profile of voriconazole. Clin Pharmacokinet 2006;45:649-63. 


\section{Table 1}

Demographic characteristics of the study patients

\begin{tabular}{|c|c|}
\hline Characteristic & Mean \pm S.D. ${ }^{a}$ \\
\hline Age (years) & $62.3 \pm 22$ \\
\hline Sex (male/female) $(n)$ & $8 / 10$ \\
\hline Weight (kg) & $65 \pm 10.2$ \\
\hline Height (cm) & $169.8 \pm 9.5$ \\
\hline Urea (mg/dL) & $53.6 \pm 41.2$ \\
\hline Body temperature $\left({ }^{\circ} \mathrm{C}\right)$ & $37.8 \pm 0.8$ \\
\hline ICU stay & $46.7 \pm 22.5$ \\
\hline SOFA score [median (range)] & $4(0-19)$ \\
\hline \multicolumn{2}{|l|}{ Admission diagnosis } \\
\hline Trauma & 10 \\
\hline Medical & 3 \\
\hline Intracerebral haemorrhage & 3 \\
\hline Subarachnoid haemorrhage & 2 \\
\hline SAPS II & $47.2 \pm 15.8$ \\
\hline Predicted mortality & $58.5 \pm 27.2$ \\
\hline APACHE II score & $20.2 \pm 7.1$ \\
\hline Predicted mortality & $23.4 \pm 23.2$ \\
\hline Observed mortality $[n / N(\%)]$ & 6/18 (33.3) \\
\hline $\begin{array}{l}\text { S.D., standard deviation; ICU, } \\
\text { Assessment; SAPS, Simplified } \\
\text { and Chronic Health Evaluation }\end{array}$ & $\begin{array}{l}\text { Intensive Care } \\
\text { Acute Physiolo }\end{array}$ \\
\hline
\end{tabular}




\section{Table 2}

Evolution of laboratory parameters

\begin{tabular}{|c|c|c|c|c|}
\hline & Baseline & Day 5 & Day 10 & EOT \\
\hline \multicolumn{5}{|l|}{ All patients } \\
\hline $\mathrm{CL}_{\mathrm{Cr}}(\mathrm{mL} / \mathrm{min})$ & $112.2 \pm 67.3$ & $98.8 \pm 57.8$ & $109.4 \pm 53.2$ & $104.6 \pm 52.6$ \\
\hline WBC count (cells/ $\mu \mathrm{L})$ & $11221 \pm 4838$ & $10589 \pm 4698$ & $9107 \pm 4368$ & $9307 \pm 4176$ \\
\hline AST (U/L) & $53.4 \pm 54.5$ & $45.4 \pm 68.2$ & $46.7 \pm 22.7$ & $80.1 \pm 103.2$ \\
\hline $\operatorname{ALT}(\mathrm{U} / \mathrm{L})$ & $81.0 \pm 112.5$ & $46.8 \pm 37.2$ & $57.91 \pm 41.9$ & $69.3 \pm 81.5$ \\
\hline ALP (U/L) & $99.6 \pm 58.9$ & $103.4 \pm 49.1$ & $125.1 \pm 44.8$ & $132.3 \pm 81.6$ \\
\hline TBIL (mg/dL) & $0.6 \pm 0.4$ & $0.9 \pm 1.4$ & $0.6 \pm 0.7$ & $1.7 \pm 2.7$ \\
\hline GGTP (U/L) & $146.5 \pm 193.3$ & $171.9 \pm 225.7$ & $164.0 \pm 122.1$ & $248.8 \pm 355.9$ \\
\hline \multicolumn{5}{|c|}{ Patients with normal $\mathrm{CL}_{\mathrm{Cr}}(>60 \mathrm{~mL} / \mathrm{min})$} \\
\hline $\mathrm{CL}_{\mathrm{Cr}}(\mathrm{mL} / \mathrm{min})$ & $140.1 \pm 57.5$ & $122.5 \pm 53.7$ & $129.4 \pm 44.2$ & $129.5 \pm 44.2$ \\
\hline WBC count (cells/ $\mu \mathrm{L})$ & $10314 \pm 5252$ & $9721 \pm 3860$ & $8004 \pm 2197$ & $7626 \pm 3208$ \\
\hline AST (U/L) & $61.5 \pm 61.7$ & $30.5 \pm 14.8$ & $46.7 \pm 25.2$ & $72.3 \pm 85.9$ \\
\hline $\mathrm{ALT}(\mathrm{U} / \mathrm{L})$ & $95.71 \pm 128.0$ & $49.7 \pm 44.5$ & $54.7 \pm 46.1$ & $84.6 \pm 104.8$ \\
\hline ALP (U/L) & $110.5 \pm 66.0$ & $101.4 \pm 45.9$ & $128.1 \pm 49.2$ & $134.9 \pm 90.9$ \\
\hline TBIL (mg/dL) & $0.5 \pm 0.2$ & $0.5 \pm 0.4$ & $0.6 \pm 0.5$ & $0.6 \pm 0.4$ \\
\hline GGTP (U/L) & $166.1 \pm 214.3$ & $128.5 \pm 96.69$ & $160.7 \pm 124.6$ & $196.3 \pm 183.7$ \\
\hline \multicolumn{5}{|c|}{ Patients with impaired $\mathrm{CL}_{\mathrm{Cr}}(40-55 \mathrm{~mL} / \mathrm{min})$} \\
\hline $\mathrm{CL}_{\mathrm{Cr}}(\mathrm{mL} / \mathrm{min})$ & $39.6 \pm 14.9$ & $12498 \pm 6237$ & $56.0 \pm 37.9$ & $54.8 \pm 25.2$ \\
\hline
\end{tabular}




\begin{tabular}{|c|c|c|c|c|}
\hline WBC count (cells $/ \mu \mathrm{L}$ ) & $12122 \pm 2379$ & $12498 \pm 6237$ & $13520 \pm 9447$ & $12668 \pm 4166$ \\
\hline AST (U/L) & $30.8 \pm 10.2$ & $78.2 \pm 122.1$ & $47.0 \pm 9.9$ & $91.0 \pm 133.9$ \\
\hline $\operatorname{ALT}(\mathrm{U} / \mathrm{L})$ & $39.8 \pm 27.3$ & $40.2 \pm 12.1$ & $72.5 \pm 4.9$ & $47.8 \pm 28.2$ \\
\hline $\operatorname{ALP}(\mathrm{U} / \mathrm{L})$ & $75.6 \pm 32.4$ & $107.8 \pm 61.1$ & $111.5 \pm 16.3$ & $128.2 \pm 73.9$ \\
\hline TBIL (mg/ & $0.9 \pm 0.5$ & $2.1 \pm 3.3$ & $0.4 \pm 0.0$ & $2.2 \pm 3.4$ \\
\hline GGTP (U/L) & $95.6 \pm 128.7$ & $267.6 \pm 388.6$ & $179.0 \pm 155.6$ & $332.8 \pm 553$ \\
\hline
\end{tabular}

EOT, end of therapy; $\mathrm{CL}_{\mathrm{Cr}}$, creatinine clearance; $\mathrm{WBC}$, white blood cell; $\mathrm{AST}$, aspartate aminotransferase; $\mathrm{ALT}$, alanine aminotransferase; ALP, alkaline phosphatase; TBIL, total bilirubin; GGTP, $\gamma$-glutamyl transpeptidase. 


\section{Table 3}

Steady-state pharmacokinetic parameters of voriconazole, estimated from the concentration-time data by non-compartmental analysis, following intravenous administration in critically ill patients $(N=18)$ with either normal renal function or moderate renal impairment

\begin{tabular}{|c|c|c|c|c|c|c|c|c|c|}
\hline \multirow[t]{2}{*}{$\begin{array}{l}\text { Patient } \\
\text { No. }\end{array}$} & \multirow[t]{2}{*}{$\begin{array}{l}\text { Dose } \\
(\mathrm{mg} / 12 \mathrm{~h})\end{array}$} & \multirow[t]{2}{*}{$\begin{array}{l}C_{\text {ave }} \text { (S.D.) } \\
(\mathrm{mg} / \mathrm{L})\end{array}$} & \multirow[t]{2}{*}{$\begin{array}{l}C_{\min } 0 \mathrm{~h} \\
(\mathrm{mg} / \mathrm{L})\end{array}$} & \multirow[t]{2}{*}{$\begin{array}{l}C_{\min } 12 \mathrm{~h} \\
(\mathrm{mg} / \mathrm{L})\end{array}$} & \multirow[t]{2}{*}{$\begin{array}{l}C_{\max } \\
(\mathrm{mg} / \mathrm{L})\end{array}$} & \multirow[t]{2}{*}{$\begin{array}{l}t_{1 / 2} \\
\text { (h) }\end{array}$} & \multicolumn{3}{|c|}{$\begin{array}{l}\text { After dose normalisation (with a mean } \\
\text { administered dose of } 272 \mathrm{mg} \text { ) }\end{array}$} \\
\hline & & & & & & & $\mathrm{CL}_{\mathrm{app}, \mathrm{ss}}(\mathrm{L} / \mathrm{h})$ & $\mathrm{Vd}_{\mathrm{app}, \mathrm{ss}}(\mathrm{L})$ & $\mathrm{AUC}_{0-12 \mathrm{~h}}(\mathrm{mg} \mathrm{h} / \mathrm{L})$ \\
\hline 1 & 240 & $0.78(0.88)$ & 0.17 & 0.15 & 2.7 & 7.0 & 38.6 & 386.6 & 8.0 \\
\hline 2 & 200 & $2.94(1.10)$ & 1.99 & 1.82 & 5.3 & 9.5 & 8.2 & 111.8 & 45.5 \\
\hline $3^{a}$ & 320 & $4.55(1.10)$ & 3.12 & 4.04 & 7.0 & 68.4 & 5.1 & 498.2 & 45.8 \\
\hline 4 & 250 & $7.73(1.51)$ & 5.62 & 5.95 & 10.4 & 8.6 & 3.0 & 36.7 & 100.6 \\
\hline 5 & 400 & $4.26(2.56)$ & 2.33 & 2.66 & 9.7 & 21.8 & 5.9 & 186.9 & 31.1 \\
\hline $6^{a}$ & 245 & $0.50(0.65)$ & $\mathrm{N} / \mathrm{A}$ & $\mathrm{N} / \mathrm{A}$ & 1.9 & 3.8 & 59.5 & 329.4 & 5.1 \\
\hline $7^{a}$ & 200 & $1.51(1.95)$ & 0.08 & 0.18 & 5.5 & 13 & 21.7 & 407.4 & 17.0 \\
\hline $8^{a}$ & 200 & $6.03(2.00)$ & 4.01 & 3.6 & 8.9 & 9.3 & 4.0 & 53.2 & 93.6 \\
\hline 9 & 320 & $1.78(1.30)$ & 0.55 & 0.72 & 4.7 & 6.3 & 14.3 & 130.1 & 16.2 \\
\hline 10 & 240 & $0.23(0.24)$ & $\mathrm{N} / \mathrm{A}$ & $\mathrm{N} / \mathrm{A}$ & 0.7 & 5.8 & 113.2 & 951.9 & 2.4 \\
\hline 11 & 200 & $0.60(0.25)$ & 0.32 & 0.40 & 1.1 & 14.3 & 39.9 & 822.5 & 9.3 \\
\hline $12^{a}$ & 300 & $4.33(2.42)$ & 2.09 & 2.10 & 9.6 & 8.1 & 5.7 & 66.8 & 42.9 \\
\hline 13 & 280 & $5.71(1.98)$ & 3.61 & 3.90 & 9.6 & 15.0 & 4.2 & 89.8 & 63.5 \\
\hline 14 & 240 & 1.09 (1.23) & 0.33 & 0.27 & 3.8 & 8.6 & 28.0 & 346.4 & 11.0 \\
\hline $15^{a}$ & 240 & 4.69 (3.71) & 0.78 & 0.8 & 11.4 & 3.7 & 5.6 & 28.8 & 55.5 \\
\hline
\end{tabular}




\begin{tabular}{llllllllll}
\hline 16 & 400 & $1.05(1.29)$ & $\mathrm{N} / \mathrm{A}$ & 0.33 & 4.1 & 7.5 & 27.3 & 296.8 & 6.8 \\
17 & 320 & $1.22(1.89)$ & $\mathrm{N} / \mathrm{A}$ & 0.44 & 5.9 & 8.1 & 24.4 & 283.6 & 9.5 \\
18 & 300 & $1.49(0.74)$ & 0.79 & 0.69 & 2.7 & 8.7 & 16.8 & 209.5 & 14.7 \\
\hline
\end{tabular}

${ }^{a}$ Patients with moderate renal impairment.

$C_{\text {ave }}$, average concentration; S.D., standard deviation; $C_{\min } 0 \mathrm{~h}$, drug concentration at $0 \mathrm{~h}$, i.e. the $12-\mathrm{h}$ sample of the previous dose; $C_{\text {min }}$ $12 \mathrm{~h}$, drug concentration at $12 \mathrm{~h} ; C_{\max }$, drug concentration at the end of infusion; $t_{1 / 2}$, elimination half-life calculated as In $2 / \lambda z$, where $\lambda z$ is the elimination rate constant estimated by log-linear regression of the terminal portion of the concentration-time curve (on the basis of the last three data points); $\mathrm{CL}_{\mathrm{app}, \mathrm{ss}}$, apparent clearance at steady state calculated as dose/AUC; $\mathrm{Vd}_{\mathrm{app}, \mathrm{ss}}$, apparent volume of distribution at steady state calculated as MRT $\times \mathrm{CL}_{\text {app,ss, }}$ where MRT is the mean residence time; AUC, area under the curve from the time of dosing to the time of next dose; N/A, not applicable. 